Volume 10. Nomor 1. June 2015
Pandecta
http://journal.unnes.ac.id/nju/index.php/pandecta

\title{
Partisipasi Masyarakat dalam Pembentukan Peraturan Daerah Tentang Penggunaan Label Batik Pekalongan
}

\author{
Mutia Silvia Rose ${ }^{\varpi}$ \\ Fakultas Hukum Universitas Negeri Semarang, Indonesia \\ Permalink/DOI http://dx.doi.org/10.15294/pandecta.v9i1.
}

\begin{tabular}{l} 
Info Artikel \\
\hline Sejarah Artikel: \\
Diterima October 2014 \\
Disetujui December 2014 \\
Dipublikasikan January 2015 \\
\hline Keywords: \\
Public Participation; Local \\
Regulation; Label Batik Peka- \\
longan
\end{tabular}

Abstrak

Partisipasi masyarakat adalah perwujudan dari masyarakat di dalam negara demokrasi, dimana pemerintahan yang di dasarkan kepada rakyat merupakan tujuan utama kehidupan berpolitik, baik dalam kebijakan maupun dalam tujuan pemerintahan. Perda Label Batik Pekalongan merupakan peraturan daerah yang mengatur tentang suatu tanda yang menunjukkan identitas dan ciri batik buatan Pekalongan yang terdiri dari tiga jenis yaitu batik tulis, batik cap atau batik kombinasi tulis dan cap. Tujuan dibentuknya Perda tersebut adalah agar masyarakat dan konsumen Batik Pekalongan tidak dirugikan akibat dari salah dalam membedakan jenis batik. Hasil penelitian ini menunjukan bahwa partisipasi masyarakat dalam pembentukan Perda tentang penggunaan label batik Pekalongan masih bersifat elitis, karena yang mendominasi mengikuti public hearing hanya pengusaha kelas atas yaitu seseorang atau kelompok orang yang memproduksi seni batik dalam bentuk tulis, cap dan kombinasi dalam jumlah besar, sudah mempunyai nama merek yang terkenal, dan pemasarannya sudah sangat luas baik di dalam negeri maupun di luar negeri. Partisipasi masyarakat dalam pembentukan perda tentang label batik pekalongan yang masih bersifat elitis dapat berpengaruh karakteristik produk hukum yang di hasilkan yaitu lebih menguntungkan pengusaha batik kelas atas, karena dalam pembuatan label batik Pekalongan merugikan dalam segi ekonomis bagi pengusaha kelas menengah dan bawah.

\begin{abstract}
Community participation is the embodiment of the people in a democracy, where the government is based on the people as the ultimate goal of political life, both in policy and administration purposes. Label the Perda Batik Pekalongan local regulation of Batik Pekalongan Label is a sign which indicates the identity and characteristics of batik from Pekalongan which consists of three types of batik, batik or batik and stamp combination. Purpose of the establishment of the regulation is that the public and consumers are not harmed Batik Pekalongan result of incorrect in distinguishing the types of batik. The result of this research indicates that participation in the formation of legislation on the use of Pekalongan batik label still elitist, because that dominate following the public hearing only top-class entrepreneurs is a person or group of people who produce batik art in written form, stamp and combinations in bulk, already has a well-known brand names, and marketing has been very widely both domestically and abroad. Public participation in the formation of regulations about labeling Pekalongan batik is still elitist may influence the characteristics of a legal product that produced batik entrepreneurs are more favorable upper classes, as in the manufacture of Pekalongan batik label in terms of economic harm to employers middle and lower classes.
\end{abstract}




\section{Pendahuluan}

Partisipasi masyarakat dalam penyelenggaraan pembangunan daerah pada dasarnya merupakan perwujudan dari masyarakat di dalam negara demokrasi, dimana pemerintahan yang di dasarkan kepada rakyat merupakan tujuan utama kehidupan berpolitik, baik dalam kebijakan maupun dalam tujuan pemerintahan.

Hal ini berarti pembangunan dalam segi kehidupan, politik, ekonomi dan sosial budaya baru berhasil apabila melibatkan partisipasi seluruh masyarakat. Partisipasi masyarakat dalam rangka kemandirian daerah merupakan aspek yang sangat penting dalam mendukung pelaksanaan otonomi daerah. Tentu saja harus di mulai dari kewenangan yang telah di miliki masyarakat itu sendiri, yaitu kewenangan yang diatur oleh perundang-undangan yang berlaku ( Sabarno, 2008: 41-42).

Masyarakat berpendapat bahwa pembentukan peraturan perundang-undangan yang baik dilakukan dengan mengetengahkan peran serta masyarakat dalam pembentukan peraturan perundang-undangan dan bertujuan untuk memenuhi ketentuan masyarakat dalam Pasal 96 Undang-Undang No.12 Tahun 2011 tentang Pembentukan Peraturan Perundang-undangan, serta peraturan lainnya yang berkaitan agar dapat memenuhi asas-asas pembentukan peraturan perundang-undangan yang baik, terutama asas dapat dilaksanakan, asas kedayagunaan dan kehasilgunaan, serta asas keterbukaan ( Indrati S, 2007: 256).

Pelaksanaan otonomi daerah yang didasarkan pada prinsip yang luas, nyata, dan bertanggung jawab mensyaratkan adanya tata kelola pemerintahan daerah yang baik. Suatu tata kelola pemerintahan yang baik dilihat dengan adanya transparansi dalam pengelolaan pemerintahan daerah, partisipasi yang aktif dari masyarakat dan akuntabilitas penyelenggaraan pemerintahan daerah. Untuk menciptakan tata kelola pemerintahan yang baik, seluruh elemen pemerintahan daerah harus senantiasa mendorong penyelenggaraan pemerintahan daerah yang transparan, partisipatif dan akuntabel (Sabarno,
2008: 37).

Memang tidak bisa dipungkiri dan harus disyukuri bahwa Indonesia banyak menyimpan kekayaan yang belum tentu di miliki oleh negara lain. Batik yang menjadi budaya bangsa, telah mampu mengangkat nama Indonesia menjadi harum di kancah internasional. Semakin terkenal suatu produk tentunya juga akan membantu meningkatkan kesuksesannya mendapatkan keuntungan yang lebih banyak.

Di Kota Pekalongan, batik tumbuh pesat dan terus dikembangkan oleh masyarakat daerah tersebut sebagai sumber mata pencaharian. Untuk motif batik pekalongan ini sangat dipengaruhi oleh keadaan daerah yang ada di sekitarnya. Hingga saat ini jenis batik pekalongan yang paling dikenal berdasarkan prosesnya adalah batik tulis dan batik cap. Meskipun demikian motif batik pekalongan tetap memiliki ciri khas yang tentunya menjadi daya tarik tersendiri untuk penggemar batik khususnya batik dari Pekalongan.

Berdasarkan UU No.23 Tahun 2014 tentang Pemerintahan Daerah, yang di maksud Pemerintahan Daerah adalah penyelenggaraan urusan pemerintahan oleh pemerintah daerah dan dewan perwakilan rakyat daerah menurut asas otonomi dan tugas pembantuan dengan prinsip otonomi seluas-luasnya dalam sistem dan prinsip Negara Kesatuan Republik Indonesia sebagaimana dimaksud dalam Undang-Undang Dasar Negara Republik Indonesia Tahun 1945 dan Otonomi Daerah adalah hak, wewenang, dan kewajiban daerah otonom untuk mengatur dan mengurus sendiri urusan Pemerintahan dan kepentingan masyarakat setempat dalam sistem Negara Kesatuan Republik Indonesia.

Sebagai manifestasi dari negara hukum kesejahteraan (Welfare State), maka Pemerintah Daerah Kota Pekalongan sebagai bagian dari Negara Indonesia berwenang membuat regulasi penggunaan label "BATIK PEKALONGAN" dimana batik pekalongan merupakan salah satu seni adiluhung dan mempunyai filosofi yang tinggi serta tata kehidupan yang mencerminkan budaya masyarakat Pekalongan yang perlu di gali, di pelihara, di lestarikan dan di lindungi. 
Perlindungan secara publik dilakukan dengan cara memanfaatkan fasilitas perlindungan hukum yang disediakan oleh ketentuan-ketentuan yang bersifat publik, seperti peraturan perundang-undangan domestik dan perjanjian-perjanjian internasional, bilateral, maupun universal,adapun perlindungan secara privat, yaitu dengan cara berkontrak secara cermat. Tetapi di dalam persaingan usaha, seperti di dunia batik ini mungkin saja pelaksanaan paten akan melanggar paten lainnya atau bahkan melanggar hukum antimonopoli atau antitrust. Pemegang paten memiliki hak ekslusif untuk melarang siapapun yang tanpa persetujuanya: (dalam paten produk) membuat, menggunakan, menjual, mengimpor, menyewakan serta menyerahkan atau menyediakan untuk dijual atau disewakan atau diserahkan produk yang diberikan paten dan (dalam paten proses) menggunakan proses produksi yang diberi paten untuk membuat barang dan tindakan lain, seperti pada paten produk ( Tangwun, 2011: 184).

Sebelum Perda ini di buat, dasar hukum yang di gunakan hanya sebatas Perwal No.47 Tahun 2012 tentang Penggunaan Label Batik Pekalongan. Perwal tidak cukup untuk kepastian hukumnya, regulasi harus dikawal dengan Perda. Jadi di buatlah Perda untuk menguatkan kepastian hukum dari label batik tersebut.

Salah satu sifat dan sekaligus merupakan tujuan dari hukum adalah memberikan perlindungan (pengayoman) kepada masyarakat. Oleh karena itu, perlindungan hukum terhadap masyarakat tersebut harus diwujudkan dalam bentuk adanya kepastian hukum (Shidharta, 2004: 112).

Peraturan Daerah Kota Pekalongan Nomor 6 Tahun 2014 tentang Penggunaan Label Batik Pekalongan di Kota Pekalongan, adalah produk hukum yang menarik karena materi yang diatur banyak bersentuhan dengan kehidupan masyarakat. Di Kota Pekalongan sebagian besar masyarakatnya merupakan pengusaha atau pedagang batik dan bahkan anggota DPRD Kota Pekalongan pun banyak juga yang berprofesi sebagai pengusaha batik kelas atas yang sudah terkenal di Pekalongan dan cukup di kenal di Indonesia. Peraturan
Daerah ini dapat memberikan jaminan terhadap pengusaha batik dan perekonomian Kota Pekalongan. Bertalian dengan pembentukan peraturan daerah yang partisipatif, di dalam nya mengandung dua makna yaitu proses dan substansi. Proses adalah mekanisme dalam pembentukan perundang-undangan yang harus dilakukan secara transparan sehingga masyarakat dapat berpartisipasi memberikan pendapat dalam mengatur suatu persoalan. Substansi adalah materi yang akan diatur harus di tujukan bagi kepentingan masyarakat luas sehingga menghasilkan perda yang demokratis berkarakter responsif (Saifudin, 2009: 5).

Dalam pembuatan peraturan daerah baiknya melibatkan masyarakat, karena di buatnya Peraturan Daerah ini dapat memberikan kesejahteraan kepada pengusaha batik, konsumen dan khususnya masyarakat Kota Pekalongan. Dalam proses pembuatan Peraturan daerah di dalamnya terdapat "Public Hearing". Public hearing ini adalah salah satu bentuk partisipasi masyarakat yang di atur dalam Pasal 96 UU No.12 tahun 2011 tentang Pembentukan Peraturan Perundangundangan. Apakah public hearing ini dapat mempengaruhi keputusan walikota untuk mengesahkan Peraturan daerah ini mengingat dalam public hearing ini dilaksanakan hanya di pertengahan pembentukan peraturan daerah oleh DPRD.

Dalam Pasal 96 ayat (1) UndangUndang No.12 Tahun 2011 tentang Pembentukan Peraturan Perundang-undangan menjelaskan bahwa masyarakat berhak memberikan masukan secara lisan dan/ atau tertulis dalam Pembentukan Peraturan Perundang-undangan. Bentuk partisipasi masyarakat di Kota Pekalongan dalam pembentukan Peraturan Daerah di sebut juga public hearing diadakan di pertengahan proses pembentukan perundang-undangan. Setiap adanya pembentukan Peraturan Daerah harus di adakan public hearing untuk melakukan diskusi dengan masyarakat Kota Pekalongan yang berkaitan dengan Peraturan Daerah yang akan di buat tersebut. Pemerintah Kota Pekalongan membuat Perlindungan Hukum untuk Batik Pekalongan sehingga di buatnya Peraturan Daerah No.6 Tahun 2014 tentang 
Penggunaan Label Batik Pekalongan.

Partisipasi dimaksudkan sebagai keikutsertaan pihak-pihak luar DPRD dan pemerintah daerah dalam menyusun dan membentuk rancangan peraturan daerah atau Perda. Ada dua sumber partisipasi; pertama dari unsur pemerintahan diluar DPRD dan pemerintah daeraah, seperti polisi, kejaksaan, pengadilan, perguruan tinggi dan lain-lain. Kedua dari masyarakat, baik individual seperti ahliahli atau yang memiliki pengalaman atau dari kelompok seperti LSM. Mengikutsertakan pihak-pihak luar DPRD dan pemerintah daerah sangat penting untuk (i) menjaring pengetahuan, keahlian atau pengalaman masyarakat sehingga Perda benar-benar memenuhi syarat peraturan perundang-undangan yang baik; (ii) menjamin Perda sesuai dengan kenyataan yang hidup dalam masyarakat; (iii) menumbuhkan rasa memiliki (sense of belonging), rasa bertanggung jawab atas Perda tersebut.

Partisipasi masyarakat tidak hanya diperlukan dalam proses penyusunan Peraturan Daerah, namun dalam seluruh tahapan pembentukannya sampai dengan evaluasi. Dalam agenda ROCCIPI-rule, opportunity, communication, capacity, interest, process, and ideology (peraturan, kesempatan, komunikasi, kemampuan, kepentingan, proses dan nilai/sikap) dinyatakan bahwa dalam penyusunan peraturan yang baik harus memperhatikan tujuh agenda tersebut. Kategori ini dapat memberikan gambaran awal reaksi masyarakat terhadap peraturan yang akan dibentuk (Rumesten, 2008:13) .

Kategori ROCCIPI mengidentifikasi faktor-faktor yang kerap menimbulkan masalah berkaitan dengan berlakunya suatu peraturan perundang-undangan. Faktor interest dan ideology merupakan faktor yang bersifat subjektif sedangkan rule, opportunity, communication, capacity, dan process merupakan faktor objektif. Dalam agenda ini terdapat faktor-faktor yang mempengaruhi peran serta masyarakat dalam pelaksanaan Peraturan Daerah berkaitan materi yang terdapat dalam Peraturan Daerah.

\section{Metode Penelitian}

Penelitian ini merupakan penelitian hukum non doktrinal dengan pendekatan socio-legal research. Melalui pendekatan ini pengkajian dilakukan dengan mendeskripsikan substansi norma-norma hukum partisipasi masyarakat dalam pembentukan Perda tentang Penggunaan Label Batik Pekalongan yaitu dalam Undang-Undang Nomor 12 Tahun 2011 tentang Pembentukan Peraturan Perundang-undangan, Perda Nomor 6 Tagun 2014 tentang Penggunaan Label Batik Pekalongan, Undang-Undang N0.23 Tahun 2014 tentang Pemerintahan Daerah dan realitas yang ada dalam partisipasi dalam pembentukan perda, serta keterkaitan antara keduanya. Secara lebih konkrit metode yang digunakan adalah metode kualitatif. Paradigma yang digunakan adalah paradigma kritis atau critical legal theory. Penelitian ini mengkritisi penyelenggaraan public hearing atau partisipasi masyarakat dalam pembentukan perda yang lebih responsif, yaitu dengan melibatkan masyarakat yang berkaitan dengan perda tetang penggunaan label batik tersebut. Penelitian ini menggunakan Konsep pemikiran Aristoteles yang membagi masyarakat dalam 3 golongan, Moh Mahfud MD yang membahas konfigurasi politik terhadap karakteristik Produk hukum dan Saifudin yang membahas partisipasi publik dalam pembentukan peraturan perundang-undangan.

\section{Hasil Penelitian dan Pembahasan}

\section{a. Partisipasi Masyarakat dalam Penyusu- nan Peraturan Daerah Tentang Penggu- naan Label Batik Pekalongan}

Dalam penyusunan peraturan daerah baiknya melibatkan masyarakat, agar masyarakat dapat menyalurkan pendapat dan masalah yang di alami dalam membangun daerahnya. Indonesia adalah negara demokrasi sehingga masyarakat berperan penting dalam penyelenggaraan negara.

Pembentukan undang-undang yang berisi tatanan kehidupan bermasyarakat, berbangsa dan bernegara merupakan bagian dari proses pengambilan keputusan yang bersifat publik. Keputusan publik yang be- 
rupa undang-undang ini akan mengikat dan berlaku bagi seluruh masyarakat dalam suatu negara. Pembentukannya harus memberikan ruang publik bagi masyarakat luas untuk ikut dalam proses pembentukannya (Saifudin, 2009: 100).

Fungsi utama adanya partisipasi masyarakat dalam suatu proses politik adalah untuk melindungi dan mengembangkan kepentingan-kepentingan rakyat dalam kehidupan suatu negara. Raperda tentang penggunaan label batik Pekalongan memiliki landasan yang baik dalam kebijakan publik di kota Pekalongan. Dalam suatu negara terdapat individu warga negara dan kesatuan-kesatuan masyarakat dengan berbagai ragam kepentingannya. Mereka akan terlibat dalam suatu partisipasi politik jika ada kepentingan di dalamnya. Melihat pada berbagai kekuatan politik yang tersebar di masyarakat, Gabriel A Almond membagi 5 hal pokok aktivitas yang mempengaruhi kebijakan pemerintah, yaitu modernisasi, perubahan-perubahan dalam struktur kelas sosial, pengaruh kaum intelektual dan komunikasi masa modern, konflik anatara kelompok-kelompok pemimpin politik dan keterlibatan pemerintah yang meluas dalam urusan sosial, ekonomi dan kebudayaan (Saifudin, 2009: 102-103).

David Easton mengemukakan bahwa partisipasi masyarakat yang berupa tuntutan dan dukungan terhadap suatu kebijakan publik merupakan input yang akan diproses dalam suatu sistem politik untuk menghasilkan suatu output bagi penyelenggaraan negara. Akan tetapi semua aktivitas inputproses-output ini memperoleh pengaruh dari lingkungannya baik internal maupun internasional. Jadi, keberadaan partisipasi masyarakat sebagai input dalam proses politik tidak dapat dilepaskan dari sistem politik dalam menghasilkan suatu outputs dalam rangka melindungi masyarakat secara luas (Saifudin, 2009: 106-107).

Masyarakat pekalongan atau pengusaha batik di Kota Pekalongan dapat mengikuti partisipasi masyarakat (public hearing) ini dan menyadari bahwa mereka tidak hanya menjadi obyek tetapi juga menjadi subyek dalam pembentukan peraturan daerah.

Aristoteles membagi masyarakat secara ekonomi menjadi kelas atau golongan yaitu Golongan sangat kaya, Golongan kaya dan Golongan miskin. Aristoteles menggambarkan ketiga kelas tersebut seperti piramida antara lain:

\section{a. Masyarakat Kelas Atas (Golongan Pertama)}

Masyarakat kelas atas atau golongan pertama merupakan kelompok terkecil dalam masyarakat. Mereka terdiri dari pengusaha, tuan tanah dan bangsawan. Yang termasuk dalam pengusaha batik pekalongan kelas atas adalah seseorang atau kelompok orang yang memproduksi seni batik dalam bentuk tulis, cap dan kombinasi dalam jumlah besar, sudah mempunyai nama merek yang terkenal, dan pemasarannya sudah sangat luas baik di dalam negeri maupun di luar negeri.

\section{b. Masyarakat Kelas Menengah (Golongan Kedua)}

Masyarakat kelas menengah atau golongan kedua merupakan golongan yang cukup banyak terdapat di dalam masyarakat. Mereka terdiri dari para pedagang, dan sebagainya.Yang termasuk dalam pengusaha batik kelas menengah adalah seseorang atau kelompok yang memproduksi batik cap, sablon dan printing yang mereknya belum cukup terkenal dan pemasarannya masih dalam cangkupan lokal atau wilayah Indonesia. Biasanya pengusaha ini memasarkan produk batiknya dengan berdagang ke luar kota.

\section{c. Masyarakat kelas bawah (Golongan ketiga) \\ Masyarakat batik kelas bawah atau go-} longan ketiga merupakan golongan terbanyak dalam masyarakat. Mereka kebanyakan rakyat biasa. Yang termasuk dalam pengusaha batik kelas bawah adalah seseorang atau buruh pengrajin batik yang bekerjasama dengan pengusaha pengusaha batik dalam pembuatan batik atau produksi batik.

Dalam pembentukan peraturan daerah tentang label batik pekalongan ini, masyarakat ikut serta dalam proses pembentukannya. Masyarakat terutama yang berkaitan dengan peraturan daerah ini diundang dalam public hearing membahas Raperda tentang penggunaan label batik pekalongan. Partisipasi 
masyarakat dalam pembentukan peraturan daerah ini dapat dilakukan secara individual dan kolektif oleh masyarakat yang berada di luar jabatan publik.

Pelaku masyarakat dalam partisipasi masyarakat mempunyai kekuatan yang termasuk dalam infrastruktur politik seperti pers, tokoh masyarakat, kelompok masyarakat, kelompok penekan, kelompok kepentingan, perguruan tinggi maupun partai politik yang tidak memperoleh wakilnya di lembaga perwakilan (Saifudin, 2009: 100). Partisipasi masyarakat dalam pembentukan peraturan daerah tentang penggunaan label batik pekalongan ini di ikuti oleh pengusaha batik pekalongan kelas atas sampai pengusaha batik pekalongan kelas bawah.

Adanya public hearing yang mulai ada di Kota Pekalongan sejak tahun 2012 ini dapat memberikan kesempatan untuk masyarakat atau pihak-pihak yang terkait dalam pembuatan perda ini untuk menyalurkan pendapatnya sesuai dalam pasal 96 ayat (1) Undang-Undang No.12 tahun 2012 tentang Pembentukan Peraturan Perundang-undangan disebutkan bahwa "Masyarakat berhak memberikan masukan secara lisan dan/atau tertulis dalam Pembentukan Peraturan Perundang-undangan". Dengan partisipasi masyarakat akan dapat mendorong terbentuknya peraturan daerah yang partisipatif.

Fungsi utama adanya partisipasi masyarakat dalam suatu proses politik ini adalah melindungi dan mengembangkan kepentingan-kepentingan masyarakat dalam kehidupan suatu negara. Tidak semua masyarakat pekalongan akan berpartisipasi dalam suatu proses pembentukan perda. Masyarakat akan berpartisipasi jika ada kepentingan dalam perda tersebut (Saifudin, 2009: 102-103).

Dalam pembuatan perda tentang penggunaan label batik pekalongan, pemerintah juga mengikut sertakan masyarakat pekalongan yang bersangkutan untuk menyalurkan pendapat-pendapatnya. Untuk melindungi kepentingan masyarakat pekalongan yang sebagian besar merupakan pengusaha batik dan pengrajin batik pemerintah membuat perda tentang penggunaan label batik ini dengan tujuan untuk memberikan pembeda pada produk batik dengan non batik, meles- tarikan dan melindungi produk batik pekalongan, menciptakan suatu bentuk identitas batik pekalongan, mendorong peningkatan kepercayaan konsumen terhadap mutu batik pekalongan, serta meningkatkan apresiasi dan citra batik pekalongan dimata nasional dan internasional (Kemenkumham, 2014).

DPRD merupakan lembaga legislatif yang juga disebut wakil rakyat. DPRD mempunyai kewenangan membuat peraturan daerah yang disesuaikan oleh kondisi yang ada di masyarakat. masyarakatpun tidak secara langsung berpartisipasi dalam pembuatan perda melainkan melalui DPRD.

Bintan R Saragih mengemukakan ada 2 cara yang dapat dilakukan oleh masyarakat dalam pembentukan peraturan daerah yaitu inisiatif masyarakat dan referendum. Inisiatif masyarakat adalah hak masyarakat untuk mengusulkan suatu Raperda kepada badan legislatif dan eksekutif dan referendum adalah permintaan atau persetujuan dan atau pendapat masyarakat apakah setuju atau tidak terhadap kebijaksanaan yang telah,sedang atau yang akan dilaksanakan oleh badan legislatif aatau eksekutif (Saragih, 1988: 163).

Dalam public hearing tentang penggunaan label batik pekalongan lebih mengacu pada cara referendum. Karena Raperda berasal dari DPRD bukan dari inisiatif masyarakat, dan masyarakat hanya dapat menyetujui atau tidak Raperda tersebut dalam public hearing.

Ada 3 macam referendum yang dikenal dalam pelaksanaan pengawasan langsung oleh rakyat antara lain referendum obligatoir (wajib), yaitu untuk berlakunya suatu perda tertentu harus terlebih dahulu mendapat persetujuan langsung dari masyarakat, referendum fakultatif yaitu referendum yang dilaksanakan apabila dalam waktu tertentu sesudah suatu perda diumumkan dan dilaksanakan, sejumlah orang-orang tertentu bersuara menginginkan diadakan referendum, dan referendum consultatif merupakan referendum yang menyangkut soal-soal teknis yang biasanya rakyat sendiri kurang paham tentang materi dari perda yang dimintakan persetujuannya (Saragih, 1988: 164).

Dalam Perda penggunaan label batik 
ini lebih cenderung pada referendum obligatoir karena perda ini di bahas dahulu dalam public hearing yang meminta pendapat dan persetujuan dari masyarakat pekalongan.

\section{b. Pengaruh Partisipasi Masyarakat terha- dap Karakteristik Penyusunan Peraturan Daerah di Kota Pekalongan}

Partisipasi masyarakat itu semakin penting urgensinya dalam proses pengambilan keputusan setelah dikampanyekannya good governance oleh Bank Dunia maupun UNDP. Salah satu karakteristik dari good governance atau tata kelola pemerintahan yang baik atau kepemerintahan yang baik adalah partisipasi. Selanjutnya UNDP mengartikan partisipasi sebagai karakteristik pelaksanaan good governance adalah keterlibatan masyarakat dalam pembuatan keputusan baik secara langsung maupun tidak langsung melalui lembaga perwakilan yang dapat menyalurkan aspirasinya. Partisipasi tersebut dibangun atas dasar kebebasan bersosialisasi dan berbicara serta berpartisipasi secara konstruktif (Sumarto, 2003: 3).

Senada dengan pengertian tersebut, Ann Seidman, Robert B. Seidman, dan Nalin Abeyserkere (2001: 8) memaknai partisipasi bahwa pihak-pihak yang dipengaruhi oleh suatu keputusan yang ditetapkan the stakeholders (pihak yang mempunyai kepentingan) memiliki kesempatan yang seluasluasnya untuk memberikan masukan, kritik dan mengambil bagian dalam pembuatan keputusan-keputusan pemerintahan.

Pengertian partisipasi tersebut tidak jauh berbeda dengan pengertian partisipasi politik yang diberikan oleh Samuel P. Huntington dan Joan M. Nelson, yaitu bahwa partisipasi politik adalah kegiatan warga negara yang bertindak sebagai pribadi-pribadi, yang dimaksud untuk mempengaruhi pembuatan keputusan oleh pemerintah (Mariam Budiardjo, 1981: 2). Ciri terpenting dari partisipasi politik langsung adalah tidak melalui proses perwakilan, melainkan warga negara berhubungan langsung dengan para pengambil keputusan. Dikaitkan dengan pendapat Herbert McClosky, bahwa partisipasi politik adalah kegiatan-kegiatan sukarela dari warga masyarakat melalui mana mereka mengam- bil bagian dalam proses pemilihan penguasa, dan secara langsung atau tidak langsung, dalam proses pembentukan kebijakan publik (Budiardjo, 1981: 1).

Dari penjelasan tersebut diatas jelas menunjukan bahwa dalam proses pengambilan keputusan, termasuk pengambilan keputusan dalam bentuk Perda, terdapat hak masyarakat untuk berpartisipasi dalam proses penyusunan Perda, yakni memberi masukan secara lisan atau tertulis dalam persiapan maupun pembahasan rancangan Perda.

Menurut Sad Dian Utomo sebagaimana di kutip dari Indra J. Piliang, manfaat partisipasi dalam pembuatan kebijakan publik, termasuk dalam pembuatan perda adalah:

1. Memberikan landasan yang lebih baik untuk pembuatan kebijakan publik.

2. Memastikan adanya implementasi yang lebih efektif karena warga mengetahui dan melihat dalam pembuatan kebijakan publik.

3. Meningkatkan kepercayaan warga kepada eksekutif dan legislatif.

4. Efisiensi sumber daya, sebab dengan keterlibatan masyarakat dalam pembuatan kebijakan publik dan mengetahui kebijakan publik, maka sumber daya yang digunakan dalam sosialisasi kebijakan publik dapat dihemat.

Bentuk-bentuk pelaksanaan partisipasi masyarakat sangat tergantung pada situasi dan kondisi masyarakat dan lingkungannya. Tingkat kualitas sumber daya masyarakat, kepedulian lembaga pendidikan atau lembaga swadaya masyarakat dan sikap pemerintah sangat mempengaruhi pola-pola partisipasi yang digunakan oleh masyarakat untuk menyalurkan aspirasinya. Adapun pengaruh partisipasi masyarakat terhadap karakteristik penyusunan Peraturan Daerah di Kota Pekalongan adalah sebagai berikut :

\section{a. Produk hukum berkarakter responsif}

Karakter suatu Undang-undang sangat di pengaruhi oleh konfigurasi politik pada waktu Undang-undang ditetapkan. Konfigurasi politik adalah suatu peta kekuatan politik dalam proses pengambilan keputusan yang 
ditujukan kepada publik dalam rangka berjalannya negara. Secara teoristis terdapat dua konfigurasi politik spektrum yang berbeda yaitu demokratis dan otoriter. Jika konfigurasi politik demokratis dapat menghasilkan karakter produk hukum yang responsif sedangkan konfigurasi politk otoriter dapat menghasilkan karakter produk hukum yang konservatif/ ortodoxs/elitis (Mahfud, 2011: 22).

Perda tentang penggunaan label batik pekalongan mempunyai karakter karena sebagaian besar masyarakat pekalongan merupakan pengusaha batik dari berbagai kelas dan akan mempengaruhi perekonomian dalam bidang usaha batik di Kota Pekalongan. Adapula pengusaha batik kelas atas yang juga merangkap sebagai anggota DPRD dan ikut memprakarsai Raperda tentang penggunaan label batik pekalongan sehingga perda ini juga dapat di pengaruhi dalam konfigurasi politik.

Moh Mahfud MD merumuskan konfigurasi politik sebagai berikut susunan sistem politik yang membuka kesempatan (peluang) bagi partisipasi masyarakat secara penuh untuk ikut aktif menentukan kebijaksanaan umum. Partisipasi ini ditentukan atas dasar mayoritas oleh wakil-wakil rakyat dalam pemilihan-pemilihan berkala yang didasarkan atas prinsip kesamaan politik dan diselenggarakan dalam suasana terjadinya kebebasan politik. Pada negara yang menganut sistem demokrasi atau konfigurasinya demokratis terdapat pluralitas organisasi dimana organisasi-organisasi penting relatif otonom. Dilihat dari hubungan antara pemerintah dan wakil rakyat, di dalam konfigurasi politik demokratis ini terdapat kebebasan bagi rakyat melalui wakil-wakilnya untuk melancarkan kritik terhadap pemerintah (Mahfud, 2011: 30-31).

Proses pembentukan perda akan di kontrol oleh masyarakat melalui berbagai bentuk partisipasi politiknya. Konfigurasi politik dan produk hukum saling berkaitan erat. Dalam setiap konfigurasi politik akan menghasilkan karakter produk hukum masing-masing. Konfigurasi politik yang demokratis akan melahirkan hukum yang responsif sedangkan konfigurasi politik yang otoriter akan melahirkan hukum yang ortodoks atau konservatif. Moh Mahfud MD mengemuka- kan dalam bukunya tentang produk hukum yang populistik yaitu "produk hukum responsif/populistik adalah produk hukum yang mencerminkan rasa keadilan dan memenuhi rasa harapan masyarakat. dalam proses pembuatannya memberikan peranan besar dan partisipasi penuh kelompok-kelompok sosial atau individu didalam masyarakat. hasilnya bersifat responsif terhadap tuntutan-tuntutan kelompok sosial atau individu dalam masyarakat (Mahfud, 2011: 31-32).

Konfigurasi politik yang digunakan di Kota Pekalongan adalah konfigurasi politik demokratis karena parpol dan parlemen yang menentukan kebijakan daerah sedangkan eksekutif (pemerintah) netral dan pers bebas, tanpa sensor dan pemberedelan sehingga karakter produk hukum yang di hasilkan bersifat responsif karena pembuatannya partisipatif, muatan nya aspiratif dan rincian isi nya limitatif.

Adanya partisipasi masyarakat dalam penyusunan peraturan daerah dapat menghasilkan produk hukum yang responsif. Produk hukum yang berkarakter responsif, proses pembuatannya bersifat partisipatif, yaitu mengundang sebanyak-banyaknya partisipasi masyarakat melalui kelompok-kelompok sosial dan individu di dalam masyarakat. Dilihat dari fungsinya maka hukum yang berkarakter responsif bersifat aspiratif. Artinya memuat materi-materi yang secara umum sesuai dengan aspirasi atau kehendak masyarakat (Mahfud, 2011:32).

\section{b. Efisiensi sumber daya}

Dengan keterlibatan masyarakat dalam pembuatan kebijakan publik dan mengetahui kebijakan publik, maka sumber daya yang digunakan dalam sosialisasi kebijakan publik dapat dihemat.

Apabila pemerintah telah memenuhi kewajiban untuk memfasilitasi partisipasi masyarakat, maka masyarakat harus mampu secara aktif dan efektif menggunakan haknya untuk melakukan pengawasan, memantau DPRD atau partai politik sehingga masyarakat dapat menjadi kekuatan kontrol tersendiri. Terdapat beberapa prinsip dasar dalam proses penyusunan perda yaitu:

\section{Transparansi/keterbukaan}


Proses yang transparan memberikan kepada masyarakat informasi tentang akan ditetapkan suatu kebijakan, dan peluang bagi masyarakat untuk memberikan masukan dan melakukan pengawasan terhadap pemerintah. Hal penting dalam proses pengambilan keputusan adalah bahwa kegiatan ini membuka kesempatan bagi masyarakat untuk dapat memberikan masukan dan pertimbangan kepada pemerintah secara langsung. Proses yang transparan haruslah mampu meniadakan batas antara pemerintah dan non pemerintah.

\section{Partisipasi}

Partisipasi mendorong terciptanya komunikasi publik untuk meningkatkan pemahaman masyarakat terhadap proses pengambilan keputusan pemerintah dan keterbukaan informasi pemerintah yang lebih baik untuk kemudian menyediakan gagasan baru dalam memperluas pemahaman komprehensif terhadap suatu isu. (Mutik, 2010:27). Partisipasi mengurangi kemungkinan terjadinya konflik dalam menerapkan suatu keputusan dan mendukung penerapan akuntabilitas, serta mendorong publik untuk mengamati apa yang dilakukan oleh pemerintah. Partisipasi publik tercermin dalam kesempatan untuk melakukan kajian terhadap rancangan keputusan, kesempatan untuk memberikan masukan dan tanggapan terhadap masukan publik dari pengambil keputusan, dalam hal ini pemerintah.

Saat ini sebagian pengusaha belum mencantumkan label batik pekalongan tersebut. Dalam hal ini pengusaha kelas menengah dan bawah beranggapan jika penggunaan label batik pekalongan ini merugikan bagi pengusaha karena harus memproduksi label batik pekalongan itu lagi. Padahal menurut DPRD label batik pekalongan itu bisa juga di sertakan dalam merk yang sudah di buat hanya saja di berikan penanda tulisan "Pekalongan" dalam warna emas, perak atau silver sehingga pengusaha tidak perlu memproduksi label batik pekalongan itu lagi, hanya cukup menyertakan di dalam merk batik.

Dalam hal ini antara Pemerintah, DPRD, dan masyarakat khususnya pengusaha batik kota Pekalongan mempunyai per- sepsi yang berbeda. Saat ini tugas Pemerintah Kota Pekalongan dalam mensosialisasikan Perda ini agar perda ini berjalan dengan baik dan dapat menciptakan kesejahteraan masyarakat Kota Pekalongan yang sebagian besar penduduknya merupakan pengusaha batik.

\section{c. Memiliki Karakteristik dari Good Gover- nance atau Tata Kelola Pemerintahan yang Baik}

Partisipasi masyarakat sebagai karakteristik pelaksanaan good governance adalah keterlibatan masyarakat dalam pembuatan keputusan baik secara langsung maupun tidak langsung melalui lembaga perwakilan yang dapat menyalurkan aspirasinya. Partisipasi tersebut dibangun atas dasar kebebasan bersosialisasi dan berbicara serta berpartisipasi secara konstruktif (Sumarto, 2003: 3).

Good governance tidak terbatas pada bagaimana pemerintah menjalankan wewenangnya dengan baik, tetapi yang lebih penting lagi adalah bagaimana masyarakat dapat berpartisipasi dan mengontrol pemerintah untuk menjalankan wewenang tersebut dengan baik.

Menurut Undang-undang No.12 tahun 2011 tentang Pembentukan Perundang-undangan :

a) Pembentukan Peraturan Perundangundangan adalah pembuatan Peraturan Perundang-undangan yang mencakup tahapan perencanaan, penyusunan, pembahasan, pengesahan atau penetapan, dan pengundangan (Pasal 1 ayat 1 ).

b) Peraturan Perundang-undangan adalah peraturan tertulis yang memuat norma hukum yang mengikat secara umum dan dibentuk atau ditetapkan oleh lembaga negara atau pejabat yang berwenang melalui prosedur yang ditetapkan dalam Peraturan Perundang-undangan (Pasal 1 ayat 2).

c) Peraturan Daerah Kabupaten/ Kota adalah Peraturan Perundangundangan yang dibentuk oleh Dewan Perwakilan Rakyat Daerah Kabupaten/Kota dengan persetujuan 
bersama Bupati/Walikota (Pasal 1 ayat 8).

Pembentukan perundang-undangan harus sesuai dengan Undang-undang yang berlaku. dan setiap daerah mempunyai produk hukum tersendiri yang di sesuaikan dengan kondisi masing-masing Daerah.

Dalam Undang-Undang No.23 Tahun 2014 tentang Pemerintahan Daerah menjelaskan bahwa pembentukan Perda Kabupaten/Kota dilakukan dengan cara :

1) membahas bersama bupati/wali kota dan menyetujui atau tidak menyetujui rancangan Perda Kabupaten/Kota;

2) mengajukan usul rancangan Perda Kabupaten/Kota; dan

3) menyusun program pembentukan Perda Kabupaten/Kota bersama bupati/wali kota.

Apabila dalam satu masa sidang DPRD dan Bupati/Walikota menyampaikan rancangan Perda mengenai materi yang sama, maka yang dibahas adalah rancangan Perda yang di sampaikan oleh DPRD, sedangkan rancangan Perda yang di sampaikan Bupati/ Walikota di gunakan sebagai bahan untuk di persandingkan.

Rancangan Perda yang telah di setujui bersama oleh DPRD dan Gubernur atau Bupati/Walikota disampaikan oleh pimpinan DPRD kepada Gubernur atau Bupati/ Walikota untuk di tetapkan sebagai Perda. Penyampaian rancangan Perda dilakukan dalam jangka waktu paling lama 7 ( tujuh ) hari terhitung sejak tanggal persetujuan bersama. Rancangan Perda di tetapkan oleh Gubernur atau Bupati/Walikota paling lama 30 (tiga puluh) hari sejak rancangan tersebut di setujui bersama. Dalam hal rancangan Perda tidak di tetapkan Gubernur atau Bupati/Walikota dalam waktu 30 (tiga puluh) hari, rancangan Perda tersebut sah menjadi Perda dan wajib diundangkan dengan memuatnya dalam Lembaran Daerah (Huda, 2009: 234-235).

Perda Penggunaan Label Batik Pekalongan termasuk Raperda prakarsa DPRD. Proses penyusunan Peraturan Daerah Prakarsa DPRD Kota Pekalongan adalah sebagai berikut :

a. Dapat diajukan oleh Anggota DPRD, Komisi, Gab. Komisi atau Badan
Legislasi

b. Disampaikan kepada Pimpinan DPRD;

c. Oleh Pimpinan DPRD, kemudian disampaikan ke Badan Legislasi Daerah untuk dilakukan Pengkajian;

d. Hasil Pengkajian Badan Legislasi Daerah disampaikan dalam Rapat Paripurna untuk ditetapkan menjadi Rancangan Peraturan Daerah Usulan DPRD

e. Disampaikan oleh Pimpinan DPRD kepada Walikota

Raperda penggunaan label batik pekalongan ini merupakan Raperda Prakarsa DPRD jadi DPRD juga merupakan unsur masyarakat. Dalam public hearing pembahasan Raperda tentang Penggunaan Batik Pekalongan ini sudah mengundang pengusahapengusaha batik di Pekalongan dan dengan di undangkan nya perda ini berarti antara DPRD dengan pemerintah sudah menjadi satu pemahaman dalam penerapan penggunaan label batik Pekalongan ini.

\section{Simpulan}

Pertama, partisipasi masyarakat dalam penyusunan Perda Nomor 6 Tahun 2014 tentang Penggunaan Label Batik Pekalongan masih bersifat elitis. Masyarakat kelas atas yang mendominasi partisipasi dalam penyusunan peraturan daerah. Hal ini sesuai dengan pendapat Aristoteles yang membagi masyarakat secara ekonomi menjadi kelas atau golongan yaitu Golongan sangat kaya, Golongan kaya dan Golongan miskin. Terdapat perbedaan antar golongan masyarakat tersebut yang mendominasi dalam penyusunan Perda nomor 6 tahun 2014 tentang penggunaan label batik Pekalongan.

Kedua, partisipasi masyarakat dalam pembentukan perda tentang label batik pekalongan yang masih bersifat elitis dapat berpengaruh pada karakteristik produk hukum yang di hasilkan. Pengusaha kelas atas lebih di untungkan dalam segi ekonomis karena pengusaha batik kelas atas tidak mempermasalahkan biaya pembuatan label batik pekalongan tersebut, sedangkan pengusaha kelas menengah dan bawah masih berfikir ulang 
tentang biaya pembuatan label batik Pekalongan.

\section{DAFTAR PUSTAKA}

Darmawan Soma, Arief. 2012. Sistem Pendukung Keputusan Peramalan Penjualan Batik di Pekalongan dengan Metode Trend Moment : Jurnal Ilmiah ICTech Vol.X No.2 mei 2012

Halim,Hamzah dan Putera Syahrul Kemal Redindo. 2009. Cara Praktis Menyusun dan Merancang Peraturan Daerah. Jakarta : Kencana

Hetifah Sj Sumarto. 2003. Inovasi, Partisipasi dan Good Governance. Jakarta : Yayasan Obor Indonesia

Huda, Ni'matul. 2009. Otonomi Daerah. Yogyakarta: Pustaka Pelajar Offset

Indrati, S Maria Farida. 2007. Ilmu Perundang-undangan 2. Yogyakarta : Kanisius

Kemilau Mutik.2010.Kedudukan Naskah Akademik Dalam Proses Pembentukan Peraturan Daerah. Tesis. Malang. Fakultas Hukum Universitas Brawijaya

MD, Moh Mahfud. 2011.(edisi evisi) Politik Hukum di Indonesia. Jakarta : PT. RajaGrafindo Persada

Manan, Bagir. 2001. Menyongsong Fajar Otonomi Daerah. Yogyakarta : PSH Fak. Hukum UII

Miriam Budiardjo, ed., 1981, Partisipasi dan Partai Politik, Jakarta : PT Gramedia.

Mutik, Kemilau . Kedudukan Naskah Akademik dalam Proses Pembentukan Peraturan Daerah : Tesis : Universitas Brawijaya

Ni Made Ari Yuliartini Griadhi dan Anak Agung Sri Utari. 2008. Partisipasi Masyarakat dalam Pembentukan Peraturan Daerah : Kertha Patrika Vol. 33 No. 1, Januari 2008

Sabarno, Hari. 2008. Memandu Otonomi Daerah Menjaga Kesatuan Bangsa. Jakarta: Sinar Grafika

Nugraha, Putra. 2008. Partisipasi Masyarakat dalam Pembentukan Peraturan Daerah : Jurnal Hukum No. 3 Vol. 15 Juli 2008

Pohan, Max H. 2000. Mewujudkan Tata Pemerintahan Lokal yang Baik (Local Good Governance) dalam Era Otonomi Daerah
Purwanto dan Zakaria. 2012. Inovasi Produk dan Motif Seni Batik Pesisiran sebagai Basis Pengembangan Industri Kreatif dan Kampung Wisata Minat Khusus : Jurnal Al Azhar Indonesia Seri Pranata Sosial Vol.1 No.4 September 2014

Rumesten, RS Iza. 2011. Model Ideal Partisipasi Masyarakat dalam Pembentukan Peraturan Daerah : Jurnal Hukum Vol.I No.2 Jurnal Jipswari 2010

Saifudin. 2009. Partisipasi Publik Dalam Pembentukan Peraturan Perundang-undangan. Yogyakarta : FH UII Press

Tangwun, Waspiah. 2011. Perlindungan Hukum Melalui Pendaftaran Paten Sederhana pada Inovasi Teknologi Tepat Guna : Jurnal Pandecta Volume 6 Nomor 2. Juli 2011

Tomy, M. Saragih. 2011. Konsep Partisipasi Masyarakat : Jurnal Sasi Vol. 17 No. 3 Bulan Juli-September 2011

Veldhuisen, Harmen C. 2007. Batik Belanda 18401940 : Dutch influence in Batik from Java. Jakarta : PT. Gaya Favorit Press

Wanty, Evi Eka. 2006. Analisis Produksi Batik Cap Dari UKM Batik Kota Pekalongan (Studi Pada Sentra Batik Kota Pekalongan-Jawa Tengah). Tesis : Universitas Diponegoro

WIPO. 2009. Analysis and Debate Of Intellectual Property Issues: The Wipo Journal No.1

\section{Peraturan Perundang-undangan}

1. Undang-Undang Dasar Republik Indonesia Tahun 1945

2. Undang-undang Nomor 23 Tahun 2014 tentang Pemerintahan Daerah

3. Undang-Undang No.12 Tahun 2011 tentang Pembentukan Perundang-undangan

4. Peraturan Daerah No.6 Tahun 2014 tentang Penggunaan Label Batik Pekalongan

5. Peraturan Pemerintah No.51 Tahun 2007 tentang Indikasi-Geografis

6. Peraturan Walikota No.47 Tahun 2012 tentang Penggunaan Label Batik Pekalongan 